\title{
PERAN INSTITUSI LOKAL DALAM PENINGKATAN EKONOMI NAGARI DIMASA PANDEMI
}

\author{
Indraddin ${ }^{\left({ }^{*}\right)}$, Zeni Eka Putri (2), Retno Anggraini ${ }^{(3)}$ \\ ${ }^{12}$ Department of Sociology, FISIP, Universitas Andalas, West Sumatra, Indonesia.
}

\section{ARTICLE INFORMATION}

$\begin{array}{ll}\text { Submitted } & : 08^{\text {th }} \text { August } 2021 \\ \text { Review } & : 01^{\text {st }} \text { October } 2021 \\ \text { Accepted } & : 17^{\text {th }} \text { Nopember } 2021 \\ \text { Published } & : 18^{\text {th }} \text { December } 2021 \\ \text { Available Online }: \text { December } 2021 .\end{array}$

\section{KEYWORDS}

Local Institution; economic improvement; covid-19

\section{CORRESPONDENCE}

*E-mail: indrazainudin@yahoo.com

\begin{abstract}
A B S T R A C T
This research aims to explore the work of local institutions in overcoming the impact of the covid-19 outbreak and improving the economy of the community in Nagari Sungai Pinang. The concept of local institutions in this study is related to values, norms, and habits in society, both at the individual, community, and institutional levels. This study uses a qualitative approach, with data collection techniques being in-depth interviews, observation, and FGD. The data were analyzed with the principles of qualitative data analysis from Miles and Huberman. The results of the study were that local institutions related to values and norms worked when the corona outbreak came. The value of helping and working together seems to encourage people to solve their own problems. Meanwhile, the value related to institutions is the role of the Nagari Traditional Kerapanan, Bundo Kanduang, and Parik Paga Nagari institutions in overcoming the COVID-19 outbreak. These local institutions are active in improving the economy of the Sungai Pinang community in agriculture, fishing, and the tourism sector. The role played by these local institutions is to encourage community members to work together to help each other, and to apply the value of land use in the agriculture, tourism, and fishing sector.
\end{abstract}

\section{A. PENDAhULUAN}

$\mathrm{P}$ andemi yang disebabkan oleh corona virus disease 2019 (covid-19) merupakan wabah penyakit yang melanda dunia. Berdasarkan pernyataan resmi world health organization (WHO), bahwa covid-19 sebagai pandemi global. Keberadaan covid-19 yang mematikan ini telah banyak menyita perhatian dunia. Ada yang menanganinya dengan sangat serius, ada pula yang seolah-olah tidak mau tahu, tapi karena hari demi hari penyebarannya semakin banyak, maka langkah kongkrit yang harus ditempuh sebagai antisipasi adalah membangun kerjasama yang baik dengan keluarga, rekan kerja, dan pihak terkait.

Dengan menyusulnya penetapan dari WHO yang menyebut wabah corona sebagai pandemi yang mempengaruhi dunia usaha, perlahan-lahan berdampak pada seluruh aspek kehidupan, terutama pada aspek ekonomi, sosial dan politik. ${ }^{1}$

Selain itu, dampak virus corona (covid-19) juga terlihat dalam kehidupan sosial masyarakat, diantaranya adalah timbulnya rasa kecurigaan dan hilangnya kepercayaan terhadap orang-orang yang ada di sekeliling kita atau yang baru kita kenal. Pada saat bertegur sapa atau bertemu baik di lingkungan kantor maupun di lingkungan rumah dan dengan masyarakat setempat kita pun enggan untuk berjabat tangan, meskipun mereka adalah orang tua, sebagaimana yang kita ajarkan kepada anak-anak kita untuk selalu menghormati orang yang lebih tua.

Selanjutnya covid-19 juga berdampak pada aspek politik yaitu bagaimana respon dan kebijakan

${ }^{1}$ Sri Mulyani. (2020). Keterangan Menteri Keuangan. Sri Mulyani, 1 April 2020. 
pemerintah pusat dan daerah dalam penanganan covid-19. Kebijakan pemerintah tersebut berkaitan dengan aspek politik yaitu tentang otonomi daerah, yang tertuang di dalam pasa 5 dan 10 Undangundang No. 4 tahun 1984 tentang wabah penyakit yang menular, upaya penanggulangan dan pembiayaan merupakan kewajiban pemerintah pusat.

2 Namun dalam urusan pembatasan transisi,, pemerintah daerah tetap terdepan dalam mengambil kebijakan atas terjadinya wabah covid-19.

Krisis keamanan juga tidak terkendali secara komprehensif dan berkeadilan dapat mengakibatkan krisis politik. Mengingat sejarah kekerasan di Indonesia, peran elite politik dengan latar belakang partai atau organisasi kemasyarakatan sebagai aktor pemicu krisis atau provokator dan dalang konflik politik bersejata patut untuk dicermati dengan seksama. Dengan ketidakpuasan publik atas kebijakan pemerintah dalam menanggulangi pandemic covid-19 berpotensi menjadi isu yang paling pertama dipolitisi. Selain itu, sentiment kesenjangan ekonomi dan kemiskinan yang makin bertambah parah di tengah masa pandemik juga kemungkinan besar akan berkembang lebih lanjut jika pemerintah gagal menyalurkan stimulus ekonomi dengan baik.

Hal yang patut diperhatikan adalah pemerintah harus menerapkan kebijakan yang proposional dalam menangani keluhan dan kritik dari masyarakat. Pendekatan persuasif dan legal berkeadilan mesti lebih diutamakan dari pada tindakan koersif. Dan untuk lembaga pengawas formal, seperti komisi I dan III Dewan Perwakilan Rakyat yang merupakan mitra kerja institusi militer dan kepolisian, juga memegang peran sentral memantau aktivitas aktor keamanan negara di tingkat pusat serta daerah. (Muhamad Haripin- Peneliti Pertahanan dan Keamanan, Pusat Penelitian Politik-LIPI) Di Indonesia, pemerintah mencoba melakukan berbagai upaya untuk menekan dampak virus corona terhadap industry. Sehingga beberapa stimulus ekonomi diluncurkan, bahkna presiden Joko Widodo meminta seluruh pihak untuk melakukan social distancing atau work from home (WFH) dan seluruh kepala daerah mengambil kebijakan untuk meliburkan kegiatan belajar mengajar. Namun beberapa kebijakan yang telah diberlakukan oleh pemerintah saja tidak sanggup, tanpa ada peran serta dari masyarakat.

Masyarakat Indonesia beranggapan pihak yang paling berpotensi mengatasi wabah corona adalah masyarakat itu sendiri. Seperti peran masyarakat untuk jaga jarak dan tetap tinggal dirumah menjadi penentu keberhasilan dalam mengakhiri covid-19 di Indonesia. Dalam masyarakat ada potensi yang bisa digerakkan untuk upaya penanganan wabah covid-19, salah satunya adalah isntitusi lokal. Institusi lokal itu bisa berupa nilai-nilai dan bisa berupa kelembagaan

2 Ida,F. (2020). Keterangan Menteri Ketenagakerjaan. Ida Fauziyah, 22 April 2020.

223 | P a g e

https://doi.org/10.25077/jantro.v23.n2.p222-229.2021 yang saling bekerjasama seperti, semua perangkat jorong (kampuang), KAN, dan Desa atau Nagari.

Pelaksanaan isolasi mandiri baik perorangan sampai kelompok dan kepatuhan dalam penerapan PSBB, kemudian berubah istilahnya menjadi PPKM (Pemberlakuan Pembatasan Kegiatan Masyarakat) mestinya bisa dilakukan di tingkat nagari. Kecamatan Koto XI Tarusan dimana nagari Sungai Pinang ada diadalamnya, pada awal pandemi memiliki kasus positif cukup banyak, dari hasil observasi awal, masyarakat lokal sangat tinggi partisipasinya dalam menanggulangi wabah Covid-19. Maka dari itu menarik untuk diteliti bagaimana peran institusi lokal bekerja mencegah dan menanggulangi dampak bencana wabah covid-19 di Nagari Sungai Pinang dan bagaimana pemanfaatan institusi lokal dalam peningkatan ekonomi masyarakat nagari.

\section{B. METODE PENELITIAN}

$\mathrm{P}$ enelitian ini menggunakan pendekatan kualitatif, yaitu penelitian yang bermaksud memberi gambaran yang mendalam, sistematis, faktual, dan akurat mengenai fakta serta hubungan antara fenomena yang diselidiki. Penelitian ini mendeskripsikan jenis-jenis institusi lokal yang mendukung peran institusi, tindakan masyarakat yang berkaitan dengan mencegah dan menanggulangi musibah covid-19, tindakan yang sudah dilakukan oleh masyarakat, ide-ide tentang pengembangan berdasarkan kelembagaan maupun keterampilan dan terakhir mendeskripsikan keikutsertaan mereka dalam tindakan pencegahan dan menanggulangi dampak ekonomi disebabkan musibah covid-19 di nagari mereka. Penggalian data dilakukan secara mendalam dengan metode wawancara. Penggalian data dilakukan setelah informan merasa percaya dan terbuka kepada peneliti, sehingga data yang diperoleh lebih valid dan mendalam. Dalam penelitian ini, peneliti melakukan observasi guna mendapat gambaran tentang aktivitas dan interaksi sosial masyarakat.

Selain menggunakan teknik wancara, obsevasi dan dokumentasi, Teknik FGD juga dipakai dalam penelitian ini. Focus group discussion (FGD) merupakan teknik pengumpulan informasi yang dilakukan, untuk lebih menggali informasi lebih banyak atau untuk mengkofirmasi data yang sudah ada kepada kelompok, yang dilakukan didalam diskusi formal maupun informal. Focus group discussion dilakukan dengan mengundang 5 sampai 7 orang tokoh masyarakat. Tempat pelaksanaan Focus group discussion umumnya di kantor wali nagari dan tempat pertemuan seperti: mushala.

Analisis data menggunakan prinsip analisis data Miles dan Huberman, dimana data yang diperoleh dari berbagai teknik penggumpulan data yang digunakan lalu dilakukan kodifikasi data. ${ }^{3}$

${ }^{3}$ Afrizal. 2014. Metode Penelitian Kualitatif. Jakarta: PT Raja Grafindo Persada, hal. 178 
Lalu data diiterpretasi dan berpedoman pada konsep dan teori yang digunakan dalam penelitian. Selanjutnya adalah tahap penarikan kesimpulan atau verifikasi, dimana peneliti menarik kesimpulan dari temuan data. Ini adalah interpretasi peneliti atas temuan dari suatu wawancara atau sebuah dokumen. Setelah dokumen diambil, peneliti mengecek kembali kesahihan interpretasi dengan cara mengecek ulang koding dan penyajian data untuk memastikan tidak ada kesalahan yang dilakukan. ${ }^{4}$

\section{HASIL DAN PEMBAHASAN}

\section{Bekerjanya Institusi Lokal dalam Penang gulangan Wabah Covid-19 di Nagari Sungai Pinang}

$\mathrm{N}$ agari Sungai Pinang termasuk nagari yang siap tanggap dalam penanggulangan wabah covid-19 ini, terlihat dengan bekerjanya institusi lokal di nagari tersebut. Ketika munculnya wabah covid-19 pada bulan Februari 2020, di Kecamatan Koto XI Tarusan terdapat kasus positif terutama di ibu kecamatan dengan terpaparnya beberapa orang tenaga medis Puskesmas Tarusan. Hal tersebut menimbulkan kecemasan dan ketakutan warga yang ada di kecamatan termasuk Nagari Sungai Pinang. Dalam kondisi cemas tersebut terlihat respon positif masyarakat untuk ikut berpartisipasi mencegah dan menanggulangi dampak yang ditimbulkan corona virus 19. Masyarakat terlihat berkerjasama baik pemerintah nagari maupun warga masyarakat bahu-membahu menjaga perbatasan nagari mereka baik dari warga yang masuk ke Sungai Pinang maupun keluar dari Sungai Pinang. Keikutsertaan masyarakat terlihat berlangsung secara spontan, tanpa ada imbalan (dibayar), masyarakat tetap mau mencurahkan waktu dan tenaga mereka. Ini menunjukkan bekerjanya institusi lokal dan kearifan lokal yang ada di Nagri Sungai Pinang.

Konsep Institusi lokal pada penelitian ini adalah dikategorikan atas nilai-nilai dan norma dan institusi lokal yang berkaitan dengan kelembagaan. Institusi lokal yang berupa nilai antara lain adanya rasa malu jika tidak ikut berpartisipasi apabila ada masalah yang dialami oleh orang maupun nagari. Sementara institusi lokal berupa kelmbagaan adalah adanya pengakuan terhadap kelembagaan yang ada di masyarakat, lalu lembaga ini berfungsi mengontrol dan menyelesaikan masalah sosial yang ada di masyarakat. Lembaga itu berupa Kerapatan Adat Nagari (KAN), bundo kanduang atau bisa jadi manifestasinya adalah kelompok PKK.

Bekerjanya institusi ini terlihat dari alasan yang diungkapkan beberapa orang informan bahwa keikutsertaanya disebabkan rasa tidak enak jika tidak ikut berpartisipasi dalam menyelesaikan masalah

${ }^{4}$ Afrizal. 2014. Metode Penelitian Kualitatif. Jakarta: PT Raja Grafindo Persada, hal. 180 yang dialami oleh masyarakat atau nagari. Nilai lain yang berlaku di tengah masyarakat adalah rasa tidak enak bagi kaum jika tidak ada anggota kaumnya yang ikut serta dalam kegiatan atau dalam aktivitas penyelesaian masalah yang dialami nagari. Nilai bekerjasama yang masih berlaku ditengah masyarakat juga muncul saat ada masalah yang diselesaikan di nagari. Nilai kerjasama itu dari dulu sampai sekarang memang masih berjalan di Nagari Sungai Pinang. Hal itu terlihat dari masih berlakunya aktivitas bergotong-royong dalam membangun fasilitas umum yang dilaksankan di nagari. Selain itu ketika ada salah seorang anggota masyarakat yang mengalami musibah seperti kebakaran, kematian atau pelaksanaan pesta (hajatan) kerjasama masyarakat bahu-membahu ikut serta menolong aktivitas tersebut.

Selain nilai, norma juga bekerja di tengah masyarakat seperti adanya pembagian kerja yang jelas berdasarkan kelompok umur atau berdasarkan gender. Pembagian kerja berdasarkan kelompok umur misalnya sudah ada saja aturan tidak tertulis ranah berpartisipasi antara pemuda dengan orang tua, antara laki-laki dengan perempuan. Ketika aktivitas menjaga nagari dari masuknya orang luar terlihat pembagian kerja antara pemuda dengan orang tua berkaitan dengan waktu. Pemuda biasanya bertugas pada malam hari sedangkan orang tua bertugas pada siang hari. Walaupun tidak ada aturan tertulis namun masyarakat mengikuti aturan tersebut dari dulu sampai sekarang. Ketika mengerjakan aktivitas lebih banyak dilakukan laki-laki, namun perempuan punya pembagian kerja yang jelas juga dimana perempuan mengantar makanan ke lokasi aktivitas yang sedang berlangsung.

Institusi lokal berkaitan dengan kelembagaan merupakan institusi yang keberadaannya merupakan manifestasi dari nilai-nilai yang berlaku di tengah masyarakat dari dulu sampai sekarang. Institusi (kelembagaan) yang ada lebih banyak berkaitan dengan nilai-nilai sosial budaya dan ekonomi. Institusi tersebut selalu eksis dan terpelihara nilai-nilai yang berlaku sesuai bidangnya. Diantara kelembagaan yang ada di Nagari Sungai Pinang adalah kerapatan adat nagari (KAN), bundo kanduang, ulama, cadiak pandai, pemuda dan parik paga nagari.

Bekerjanya institusi lokal yang ada di Nagari Sungai Pinang. Seperti kerjasama, tolong-menolong, nasehat-menasehati. Nilai-nilai itu dilaksanakan oleh institusi sesuai fungsinya masing-masing yang terwujud dalam kelembagaan KAN, Ulama, Cadiak Pandai, Bundo Kanduang, Pemuda dan Parik Paga nagari yang saling berkoordinasi dan didukung oleh seluruh masyarakat. Aktivitas tersebut dapat terlihat dari kegiatan yang dilakasanakan antara lain :

Pertama dengan melakukan penutupan jalan akses dari Padang menuju Nagari Sungai Pinang ketika mulai datangnya wabah bulan April tahun 2020. Sistem yang diberlakukan dalam penutupan jalan ini yaitu, setiap ada orang yang masuk ke Nagari Sungai Pinang harus dicek dulu temperatur suhu badan dan disemprot dengan disinfektan orang tersebut terlebih 
dahulu. Setelah itu ditanya tujuannya secara detail ke Nagari Sungai Pinang, jika tujuan orang tersebut penting diperbolehkan untuk masuk atau hanya sekedar melawati, apabila tujuannya tidak penting orang tersebut disuruh putar balik menuju Kota Padang kembali. Penutupan jalan ini dilakukan selama 2 bulan yang dijaga oleh pemuda dan masyarakat setempat, dengan sistem bergantian. Kegiatan penutupan akses jalan ini dilakukan selama 4 bulan berturut-turut yang dimulai dari bulan Maret, April, Mei dan Juni 2020 semenjak wabah covid-19 yang membuat masyarakat ketakutan. Pentupan akses jalan yang dilakukan selama 4 bulan di Nagari Sungai Pinang berjalan dengan sukses, semua itu atas partisipasi masyarakatnya yang tinggi. Sehingga tidak ada masyarakatnya yang terindikasi covid-19 sampai awal tahun 2021.

Kedua pembagian masker dari pihak Nagari yang saling bekerjasama dengan KAN, Ulama, Cadiak Pandai, Bundo Kanduang, Pemuda dan Parik Paga dalam nagari, kepada seluruh masyarakat Nagari Sungai Pinang. Serta diwajibkan kepada seluruh masyarakat untuk memakai masker tesebut. Baik ketika keluar rumah di sekitar lingkungan tempat tinggal saja, maupun pada saat pergi ke mesjid, ke pasar, acara baralek dan pada saat acara pertemuan lainnya.

Ketiga semua orang luar yang masuk ke Nagari Sungai Pinang, tidak diperbolehkan untuk beribadah di Mesjid yang berada di Nagari Sungai Pinang, kalau masih ada orang luar yang tetap beribadah di Mesjid tersebut, pemuda dan masyarakat setempat secara inisiatif akan langsung menegurnya. Ini berlangsung terutama pada awal wabah covid-19 terjadi antara bulan Maret sampai bulan Juni 2020. Saat tidak lagi berlaku Pembatasan sosial berskala besar (PSSB) di Sumatera Barat, masyarakat Nagari Sungai Pinang juga membuka akses terhadap pendatang masuk ke Nagari Sungai Pinang.

Keempat selalu memberitahukan kepada masyarakat untuk selalu jaga jarak di tempat keramaian yang dikunjungi serta dilarang juga untuk berkumpul-kumpul di warung, dan juga mengajak masyarakat untuk selalu cuci tangan pakai sabun dan menyediakan tempat cuci tangan di tempat-tempat umum, seperti di jalan masuk ke Nagari Sungai Pinang, di kantor wali Nagari Sunagai Pinang dan di masjid atau mushalla. Seiring berlakunya new normal di Sumatera Barat masyarakat Sungai Pinang terlihat mulai menjalankan aktifitas mereka secara normal seperti semula. Dalam berinteraksi sesama masyarakat nagari tampa disertai orang luar masyarakat mulai tidak menggunakan masker dalam berinteraksi seperti di warung (lapau) atau tempat ibadah.

Kelima mereka saling berbagi dalam kehidupan sehari-hari terutama dalam pemenuhan kebutuhan kehidupan sehari-hari seperti, meminjamkan beras, cabe bagi yang tidak memiliki. Saat ada nelayan yang berhasil mendapatkan ikan akan membagi hasilnya kepada yang tidak mendapatkan, terutama untuk konsumsi rumah tangga.
Dari beberapa aktifitas yang telah dilakukan oleh masyarakat Nagari Sungai Pinang, yang saling bekerjasama dengan seluruh kelembagaan yang ada dii nagari seperti KAN, Ulama, Cadiak Pandai, Bundo Kanduang, Pemuda dan Parik Paga nagari dalam mencegah wabah covid-19 ini sudah berhasil. Karena adanya kerjasama yang baik dan saling peduli satu sama lain antara masyarakat dengan KAN, Ulama, Cadiak Pandai, Bundo Kanduang, Pemuda dan Parik Paga nagari. Sehingga tidak ada satupun masyarakat yang terindikasi oleh virus covid-19 di Nagari Sungai Pinang.

Kehidupan masyarakat di Nagari Sungai Pinang memiliki prinsip hidup yang saling membantu, saling berbagi dan sistem bergoto-royong. Prinsip dalam saling membantu dan berbagi ini memang sudah ada sejak dulu sampai saat terjadinya wabah corona-19, namun nilai-nilai tersebut terlihat lebih aktif dan berfungsi saat terjadi wabah corona-19. Artinya dalam suasana ada tantangan dari luar institusi lokal dan kearifan lokal bekerja lebih efektif. Bila konteks tersebut dimanfaatkan untuk meningkatkan taraf kehidupan masyarakat, akan menimbulkan kebiasaan baru yang dapat meningkatkan fungsi dan produktifitas dalam masyarakat. Pemimpin mestinya arif memanfaatkan moment tersebut untuk menggerakkan partisipasi masyarakat dalam bidang ekonomi. Selanjutnya ada kerjasama dalam sistem menanam padi yang kelompok tersebut terbentuk secara spontan, yang disebut "balanbiah hari", yaitu maagihan hari awak ka urang diagiahan lo hari urang ka awak (setiap ada hari lowong, tanpa diundang seseorang pergi bekerja ke lahan orang lain), ini yang akan menimbulkan rasa hutang bagi orang tersebut, sehingga orang tersebut akan membayarnya dengan pergi kesawah orang itu lagi, atau ketika kita membantu orang lain, orang tersebut akan membantu kita juga. Prinsip kehidupan yang telah ada di masyarakat masih tetap ada sampai saat ini, baik sebelum terjadi wabah covid-19 atau dengan adanya wabah covid-19 saat ini.

\section{Dampak Wabah Covid-19 Terhadap Munculnya Peran Serta Masyarakat dan Institusi Lokal Yang Dimiliki Masyarakat Nagari Sungai Pinang.}

Sungai Pinang yang memiliki potensi wisata, sebagian masyarakat beralih profesi menjadi pedagang dan usaha pariwisata. Disaat wabah corona menyerang sektor ini terdampak. Secara umum dalam aktifitas ekonomi tidak terlihat dampak yang signifikan akibat wabah corona, karena saat wabah terjadi tidak ada larangan terhadap aktifitas mata pencaharian masyarakat dalam bidang pertanian dan nelayan. Kecuali dalam bidang pariwisata. Aturan pembatasan sosial berskala besar (PSSB) yang diberlakukan pemerintah provinsi terhadap penutupan sementara objek wisata tentu berpengaruh terhadap aspek ekonomi dalam bidang pariwisata. 
Dalam pemasaran hasil tangkapan ikan pengaruh wabah cukup dirasakan oleh nelayan, karena pemasaran ikan hasil tangkapan nelayan banyak dijual ke pasar Gaung Kota Padang. Pembatasan sosial berskala besar (PSBB) yang diberlakukan ketat di Kota Padang mengakibatkan pasar Gaung sebagai tempat pemasaran ikan Nelayan Nagari Sungai Pinang sepi dari pembeli. Selain dari ketakutan masyarakat mengunjungi pasar juga disebabkan menurunnya daya beli masyarakat di Kota Padang, sehingga kesulitan pemasaran hasil tangkapan ikan berdampak kepada nelayan Nagari Sungai Pinang. Sedangkan ekonomi nelayan dan petani sawah tidak ada dampaknya, karena mereka tidak ada larangan untuk ke laut ataupun ke sawah pada saat wabah covid-19 tersebut.

Selanjutnya jika kita lihat dari kondisi pendidikan untuk anak-anak Indonesia karena wabah corona ini sangat memprihatikan, termasuk di Nagari Sungai Pinang. Sistem belajar online ini juga membuat orang tua tidak mampu membelikan handpone untuk anaknya, sehingga anaknya menumpang belajar ke teman-temannya. Ada orang tua yang mampu membelikan handpone untuknya, tapi tidak sanggup membelikan paket internet untuk belajar online tersebut. Dikarenakan dalam sistem belajar online ini guru banyak memberikan tugas, para orang tua dan anaknya sulit mengirim karena internet untuk mengirimkan tugas tersebut kurang. Hal seperti ini sangat tidak efektif untuk pendidikan anak-anak.

Jadi wabah covid-19 ini berdampak kepada keseluruh aspek yang ada dimasyarakat, terutama pada sistem ekonomi dan pendidikan di Nagari Sungai Pinang.

\section{Potensi Institusi Lokal Dalam Peningkatan Ekonomi Nagari di Sungai Pinang.}

Ada tiga jenis potensi ekonomi yang terdapat di Nagari Sungai Pinang, pertama dari sektor kelautan. Letak nagari yang berada di pantai barat pulau sumatera dengan adanya teluk yang menjorok di nagari, memiliki potensi besar untuk usaha perikanan. Hal ini memang telah dilakoni oleh masyarakat Nagari Sungai Pinang dari dahulu sampai sekarang. Dengan lokasi daerah yang berupa teluk tentu membuat nelayan aman menambatkan kapalnya di sepanjang pantai, karena cukup terlindung dari fenomena alam (badai dan ombak besar). Dengan demikian sektor nelayan merupakan salah satu potensi besar untuk dikembangkan guna meningkatkan ekonomi masyarakat di Nagari Sungai Pinang. Institusi lokal berkaitan dengan ini masih terjaga, seperti adanya kelompok jarring tepi, tuo pasie, serta aturan main dalam menangkap ikan masih terjaga dan dipedomani masyarakat nelayan Sungai Pinang. Maka pemberdayaan ekonomi di sektor perikanan merupakan salah satu potensi yang bisa dikembangkan untuk peningkatan ekonomi di Nagari Sungai Pinang.

Institusi lokal berkaitan dengan bidang nelayan bekerjasama dengan kelembagaan adat mendorong anak kemenakan untuk meningkatkan hasil tangkap dengan melengkapi alat tangkap seperti jarring dan kapal. Dengan berkoordinasi dengan pemerintah nagari diusahakan bantuan untuk anakkemenakan mendapatkan bantuan kapal motor, sehingga hasil tangkap bisa ditingkatkan.

Kedua sektor pertanian, memiliki potensi besar juga untuk dikembangkan guna meningkatkan ekonomi masyarakat. Potensi pertanian terdiri dari pertanian sawah, pertanian ladang dan perkebunan. Sawah lebih kurang 100 ha yang terdapat di Nagari Sungai Pinang memiliki tingkat kesuburan yang cukup tinggi. Luas sawah yang tersedia paling tidak dapat mencukupi kebutuhan beras masyarakat di nagari. Selain ketersedian lahan tenaga petani yang tersedia cukup banyak, karena penduduk yang berprofesi sebagai nelayanpun juga memiliki keterampilan dalam bertani.

Sudah ada kelompok tani di nagari, namun kelompok tersebut sering muncul karena adanya program bantuan pemerintah dalam pertanian, belum tumbuh dari bawah sesuai kebutuhan petani itu sendiri, sehingga belum terwujud oragnisasi yang baik. Institusi lokal yang bekerja peningkatan ekonomi berkaitan dengan pemanfaatan lahan adalah peran serta mamak kaum dalam pengelolaan tanah ulayat. Pada masa pandemic, muncul gagasan dari ketua KAN untuk meningkatkan nilai tambah pemanfaatan lahan petanian. Ninik mamak menggagas pemanfaatan lahan tidur untuk ditanami pinang. Caranya adalah mendistribusikan lahan kosong kepada anak kemanakan di kaum masing-masing, lalu diberi dukungan modal untuk ditanami pinang dengan luas satu sampai dua hektar. Nagari menyediakan bantuan bibit pinang untuk petani lalu diberi biaya operasional sebesar Rp1.500.000,- setiap bulan. Namun aturan keuangan belum membolehkan memberikan uang berupahonor kepada pemilik tanah, maka yang bisa dibantu adalah bibit dan peningkatan keterampilan bagi petani.

Ketiga sektor pariwisata, merupakan potensi baru yang dapat dimanfaatkan oleh masyarakat Nagari Sungai Pinang semenjak dibukanya kawasan wisata bahari mandeh dimana Nagari Sungai Pinang merupakan salah satu nagari penyangga dalam kawasan tersebut. Dengan adanya beberapa lokasi pantai yang dapat dikembangkan sebagai destinasi wisata, membutuhkan daya dukung baik dari sisi sumber daya manusia maupun modal investasi. Destinasi wisata yang terdapat di Nagari Sungai Pinang ada sebagai berikut: Wisata Batu Kucing, Wisata Dina Cheker atau Batu Kajang, Wisata Pantai Maparalam, Wisata Echo Beach Camp Learn Form Nature and Positively dan Wisata Manjuto Beach Homesta. Dari enam lokasi yang sudah dikembangkan tersebut 5 diantaranya dikembangkan oleh masyarakat Nagari Sungai Pinang itu sendiri, hanya satu saja yang dikembangkan oleh orang luar Nagari Sungai Pinang.

Selain wisata pantai wisata ekologi dan agrowisata juga berpotensi untuk dikembangkan, saat ini sudah dimulai pengembangan wisata manggrove yang bekerjasama dengan balai pengelola daerah 
aliran sungai (BPDAS). Selain itu WARSI juga sudah mulai bermitra dalam penataan lingkungan terutama lingkungan hutan sejak tahun 2017. Dengan demikian terlihat kalau institusi lokal berkaitan dengan pelestarian lingkungan juga sudah ada di tengah masyarakat.

Peran Institusi lokal yang telah melihatkan hasil, mengundang simpati perusahaan di sekitar untuk membantu dengan program dana CSR. Sekarang akan dibangun jembatan penghubung lahan mangrove sebagai salah satu daya tarik wisata, Dengan peningkatan kualitas destinasi wisata, dengan berkurangnya wabah pandemic, kunjungan wisata mulai meningkat ke Sungai Pinang. Peningkatan kunjungan tentu akan memberi peluang kepada masyarakat untuk mengembangkan usaha pariwisata.

\section{Langkah-Langkah Pemberdayaan Masyarakat Guna Peningkatan Ekonomi}

\section{Dalam Bidang Perikanan}

Berdasarkan identifikasi potensi sektor perikanan perlu dilakukan langkah-langkah pengembangan sektor perikanan. Langkah pertama melakukan identifikasi tenaga nelayan yang ada di nagari, yaitu atas keahlian yang dimiliki nelayan. Langkah Kedua perlu identifikasi atas umur nelayan. Ketiga perlu identifikasi atas kepemilikan kapal, keempat perlu identifikasi institusi lokal yang potesial mendukung pengembangan sektor perikanan. Selanjutnya Langkah kedua melakukan klasifikasi. Klasifikasi dilakukan atas nelayan yang terampil dan nelayan kurang terampil, klasifikasi atas nelayan sebagai pengusaha dan nelayan sebagai buruh.Terkahir yang ketiga tahap peningkatan kapasitas. Tahap peningkatan kapasitas ini dilakukan dalam bidang aspek permodalan, aspek keterampilan, aspek pengorganisasian.

\section{Dalam Bidang Pertanian}

Berdasarkan Langkah pertama melakukan identifikasi atas petani pemilik modal, petani penggarap dan buruh tani. Langkah ini perlu dilakukan untuk mendapatkan informasi siapa yang menjadi pemilik lahan siapa yang menjadi penggarap atau penyewa dan siapa petani yang menjadi buruh tani. Langkah kedua Identifikasi potensi lahan. Identifikasi ketersedian alat sarana dan alat pertanian. Selanjutnya Langkah kedua melakukan klasifikasi atas petani pemiliki atau yang memiliki modal dengan yang tidak memiliki modal. Klasifkasi petani yang atas petani sawah, petani ladang dan petani perkebunan, atas petani terampil dengan petani kurang terampil.

\section{Dalam Bidang Pariwisata}

Pertama identifikasi spot-spot yang berpotensi yang dikembangakan sebagai wisata lokasi pantai. Indentifikasi pemilik lahan terhadap lokasi yang berpotensi yang dijadikan wisata. Identifikasi kemampuan pemilik lahan untuk pengembangan lokasi wisata. Identifikasi keahlian dan keterampilan tenaga pelayan usaha pariwisata. Identifikasi potensi kuliner yang dimiliki daerah yang bisa dipromosikan dan dijual di lokasi wisata. Identifikasi ganguan keamanan di lokasi pariwisata. Kedua Langkah klasifikasi terhadap pengembangan pariwisata. Pertama klasifikasi landscape, apakah termasuk wisata pantai atau pemandangan alam. Kedua klasifikasi luas lahan, apakah termasuk luas yang bisa dibangun fasilitas yang komplek atau fasilitas sederhana. Ketiga klasifikasi atas kemampuan pemilik lokasi yang mampu memngembangkan sendiri atau bermitra dengan orang lain.

\section{Analisis Kelayakan Pengembangan Sektor Ekonomi}

Dari tiga sektor ekonomi yang dimiliki Nagari Sungai Pinang, yaitu nelayan, pertanian dan pariwisata tentu perlu dibuat skala prioritas dalam pengembangannya. Analisis SWOT dapat melihat kekuatan, kelemahan, peluang dan ancaman yang dimiliki setiap sektor ekonomi yang ada. Sektor perikanan memiliki kekuatan adanya teluk yang cukup bagus untuk menangkap ikan. Teluk yang sempit dengan pantai yang tidak ada karang memungkinkan ikan yang datang gampang ditangkap dan jaring (pukek) dapat dibentang dan ditarik dengan mudah oleh nelayan.

Namun kelemahannya adalah lokasinya sangat kecil sehingga tidak memungkinkan nelayan mengoperasikan jaring dalam jumlah yang banyak pada waktu yang sama. Sehingga dari hasil observasi terlihat nelayan menggelar jaringnya atau dalam bahasa setempat malilik dilakukan secara bergantian. Peluang terhadap usaha tangkap ikan memiliki pasar yang luas karena bisa dipasarkan di luar Nagari Sungai Pinang. Biasanya nelayan memasarkan hasil tangkapnya sampai ke Carocok Tarusan dan Kota Padang. Namun ancamannya adalah ketika hasil ikan dari Kota Padang dan daerah lain banyak ikan hasil tangkap nelayan Nagari Sungai Pinang sulit untuk dijual sehingga harganya rendah. Jadi dengan kondisi seperti sekarang dimana nelayan hanya mengandalkan sistem tangkap dengan jarring tepi (pukek tapi) dengan menggunakan ukuran perahu yang kecil sulit rasanya mengandalkan sektor perikanan ini menjadi andalan peningkatan ekonomi masyarakat Nagari Sungai Pinang. Bila dikembangkan sistem tangkap dengan kapal besar masyarakat mengaku tidak mampu mengoperasikan karena mahalnya modal yang dibutuhkan (biaya yang dikeluarkan tidak signifikan dengan hasil tangkap). Begitupun sistem tangkap (pukek tapi) sangat ditentukan oleh cuaca serta banyak sedikitnya ikan yang datang kepinggir pantai (teluk) yang ada di Nagari Sungai Pinang.

Sektor pertanian memiliki kekuatan antara lain ketersedian lahan yang cukup luas. Pertama ada lahan sawah sekitar lebih kurang 200 ha dengan tingkat kesuburan yang baik dan ketersedian air yang cukup. Apabila sawah berproduksi dengan baik dapat mencukupi kebutuhan beras masyarakat Nagari 
Sungai Pinang. Petani di Nagari Sungai Pinang tersedia dengan cukup dan memiliki keterampilan yang baik dalam berbudidaya tanaman padi. Selain sawah juga tersedia lahan pertanian lading. Lahan pertanian lading biasanya ditanami tanaman palawija dan tanaman perkebunan seperti jengkol, petai, pinang dan tanaman buah-buahan seperti durian, nangka, jambu dan rambutan. Namun kelemahannya adalah masyarakat belum terbiasa mengolah lahan pertanian secara profesional, sehingga hasilnya belum optimal. Peluang mengembangkan pertanian antara lain masih banyak lahan tidur yang belum digarap. Pasar hasil pertanian tidak mengalami kendala, bahkan selama ini terhadap hasil perkebunan seperti jengkol dan pinang diperebutkan oleh pedagang. Pemerintah juga mendukung terhadap pengembangan pertanian, apalagi kalau masyarakat aktif dan bisa memanfaatkan peluang bantuan dari pemerintah. Contohnya saat ini pemerintah membantu bibit manggrove yang dikembangkan di Nagari Sungai Pinang. Ancaman terhadap pertanian hampir tidak ada paling adanya serangan hama baik hama penyakit tanaman maupun hama penyerang yang berasal dari hewan seperti monyet.

Sektor pariwisata memiliki kelebihan pertama tersedianya lahan yang bisa dikembangkan sebagai lokasi wisata, berada dipinggir pantai dengan pemandangan yang indah dan pasir putih yang menawan. Bibir pantainya landai sehingga tidak membahayakan bagi pengunjung yang ingin mandi dan bermain di tepi pantai. Akses jalan menuju lokasi wisata cukup bagus dan bisa tempuh oleh kendaraan bermotor baik roda dua dan empat atau lebih. Masyarakat setempat juga welcome terhadap pengujung yang datang ke lokasi wisata. Kelemahannya adalah sedikit jumlah penduduk yang memiliki lokasi yang berpotensi dikembangkan sebagai lokasi wisata. Mulai dari pemukiman penduduk sampai ke batas nagari yaitu nagari sungai nyalo hanya 9 lokasi dan Sembilan pemilik yang bisa dikembangkan sebagai lokasi wisata pantai. Tidak semua pemilik lokasi yang memiliki modal untuk pembangunan lokasi sebagai usaha pariwisata. Peluangnya besar karena Nagari Sungai Pinang merupakan salah satu nagari penyangga di kawasan wisata bahari mandeh yang merupakan salah satu program wisata nasional. Selain itu lokasi ini mudah dijangkau dari kota padang sebagai ibukota provinsi.
Ancamannya adalah adanya competitor yaitu lokasi wisata di ibukota Pesisir Selatan Painan juga lokasi wisata yang ada di sekitar Nagari Sungai Pinang seperti Nagari Sungai Nyalo dan Nagari Mandeh.

Dari analisis kekuatan dan kelemahan yang dilakukan terhadap tiga sektor potensi ekonomi yang dapat dikembangkan di nagari sungai pinang, sektor pertanian merupakan sektor yang paling strategis untuk dikembangkan karena tingginya kelebihan kecilnya kelemahan dan besarnya peluang serta kecilnya ancaman dari luar terhadap pengembangan sektor ini.

\section{KESIMPULAN}

W abah Covid-19 selain berdampak terhadap aspek kesehatan, juga berinbas kepada aspek ekonomi karena dengan terjadinya pembatasan gerakan masyarakat. Untuk mengatasi masalah ini tidak cukup peran pemerintah saja, tapi partisipasi masyarakat sangat dibutuhkan. Di nagari Sungai Pinang peran institusi lokal cukup membantu penyelesaian dampak covid-19. Institusi lokal yang bekeja terdiri dari nilai dan norma yang masih dianut oleh masyarakat, serta kelembagaan yang ada di tengah masyarakat yang bekerja atas nilai dan norma yang masih mendapat dukungan masyarakat. Nilai bekerjasama dan norma tolong-menolong di masa pandemi terlihat dapat meningkatkan ekonomi di sektor pertanian, nelayan dan pariwisata. Kelembagaan KAN beserta ninik mamak yang ada didalamnya telah mendukung usaha pertanian dan pariwisata berkaitan dengan pengelolaan lahan.

\section{E. UCAPAN TERIMAKASIH}

$T$ erimakasih penulis sampaikan kepada pimpinan FISIP dan LPPM Univesitas Andalas dan pemerintah Nagari Sungai Pinang atas fasilitasinya untuk melaksnakan riset ini. Hal serupa juga penulis sampaikan kepada wali nagari atas pemberian izinnya. Tokoh masyarakat seperti niniak mamak, alim ulama, cadiak pandai dan para informan atas keterangannya, sehingga penelitian/penulisan artikel ini dapat diselesaikan sesuai rencana.

\section{DAFTAR PUSTAKA}

Afrizal. 2014. Metode Penelitian Kualitatif. Jakarta: PT Raja Grafindo Persada.

Abbeduto, L. (2004). Taking Sider: Clashing Views on Controversial Issues in Educational Psychology Third Edition. Dushkin.

Amirudin, C., \& Sabiq, A. F. (2021). Peran Ziswaf dalam Memulihkan Ekonomi Umat Akibat Masa Pandemi Covid-19. Jurnal BAABU AL-ILMI: Ekonomi Dan Perbankan Syariah, 6(1), 38.

Bungin, B. (2003). Metodologi Penelitian Kualitatif. Rajawali Press.

Chambers. (1985). Chambers, R. 1985. Rural Development: Putting The Last First. London: New York. New York. 
Covid-, D. M. P. (2021). Jurnal Antropologi: Isu-Isu Sosial Budaya |. 01(June), 27-36.

Friedman, J. (1992). Friedman, Jhon. 1992. Empowerment The Politics of Alternative Development. Blackwell Publishers. Cambridge, USA. US

Hamid, Hendrawati. (2018). Manajemen Pemberdayaan Masayarakat. Makassar:Della Massa.

Haniifah, F. N., Pembajeng, G. S., Izzati, H. N., \& Azalea, Z. K. (2021). Peran Kelembagaan Dalam Penanganan Covid-19 Di Indonesia The Role Of Institutions In Handling Covid-19 In Indonesia Covid-19. January, 1-11.

Horton, P. B. dan C. L. H. (1984). Sociology, edisi kedelapan. McGraw-Hill.

Ida,F. (2020). Keterangan Menteri Ketenagakerjaan. Ida Fauziyah, 22 April 2020.

Indraddin \& Gusmini. (n.d.). (2017).Peran Institusi Lokal dalm Mewujudkan Nagari Mandiri Pangan untuk Pengentasan Kemiskinan. Vo 7, No. 2, 2017. 2017, Vo 7.

Indraddin \& dkk. (2019). Model Pemberdayaan Institusi Lokal Masyarakat Menghadapi Mandeh sebagai Nagari Wisata Kuliner. Fakultas IImu Sosial dan Politik. Universitas Andalas. Padang.

Jimu, M.. (2008). Community Development, Community Development: A Cross-Examination of Theory and Pratice Using Experiences in Rural Malawi. Vol. XXXII(A Cross-Examination of Theory and Pratice Using Experiences in Rural Malawi.), PP. 23-3

Literate, S., \& Indonesia, J. I. (2020). View metadata, citation and similar papers at core.ac.uk. 274-282.

Literate, S., \& Indonesia, J. I. (2020). View metadata, citation and similar papers at core.ac.uk. 274-282.

Moeleong, L. (2004). Metodologi Penelitian Kualitatif Edisi Revisi. PT Remaja Rosdakarya.

Nasrul, W. (2013). Peran Kelembagaan Lokal Adat Dalam Pembangunan Desa. Jurnal Ekonomi Pembangunan: Kajian Masalah Ekonomi Dan Pembangunan, 14(1),102.

Njalo, K., \& Menghadapi, D. (2021). Jurnal Antropologi: Isu-Isu Sosial Budaya |. 01(June), 83-92.

Pitana, I. G. E. al. (2005). Sosiologi Pariwisata. CV Andi Offset.

Priyono dan Herry. (2002). Anthony Gidden: Suatu Pengantar. Kepustakaan Populer Gramedia.

Ritzer, G. dan D. J. G. (2004). Teori Sosiologi Modern. Kencana.

Saprudin, R. \& dkk. (2016). Peran Institusi Dalam Kegiatan Pembangunan Masyarakat: Kasus Punggawa Ratu Pasundan dalam Program Desa Wisata di Desa Sukaratu Kecamatan Gekbrong Kabupaten Cianjur.

Satria, A. (2020). Kearifan Lokal Dalam Menghadapi Pandemi Covid-19: Sebuah Kajian Literatur. Sosietas, 10(1), 745-753.

Sipahelut, M. (2010). Analisis Pemberdayaan Masyarakat Nelayan di Kecamatan Tobelo Kabupaten Halmahera Utara. IPB.

Sri Mulyani. (2020). Keterangan Menteri Keuangan. Sri Mulyani, 1 April 2020.

Suharto, E. (2005). Membangun Masyarakat Memberdayakan Rakyat. Kajian Strategi Pembangunan Sosial dan Pekerjaan Sosial. PT Refika Aditama.

Wilson, T. (1996). The Empowerment Mannual. Grower Publishing Company.

Valentina, T. R., Putera, R. E., \& Safitri, C. (2020). Analisis Pemanfaatan Dana Desa Pada Masa Pandemi Covid-19 Di Nagari Talang Anau Kabupaten Lima Puluh Kota. Prosiding Simposium Nasional Multidisiplin, 2, 124-132. http://jurnal.umt.ac.id/index.php/senamu/article/view/3447 